\title{
Clear Cell Variant Thyroid Gland Follicular
} Carcinoma

National Cancer Institute

\section{Source}

National Cancer Institute. Clear Cell Variant Thyroid Gland Follicular Carcinoma. NCI

Thesaurus. Code C46096.

A morphologic variant of follicular carcinoma of the thyroid gland characterized by the predominance of malignant follicular clear cells. These cells lack the nuclear features that characterize the papillary carcinomas of the thyroid gland. 